\title{
Characterization of Pantoea Sp. Strain MK1D, and Erwinia Sp. Strain MK2Y as Tricalcium Phosphate Dissolving Bacteria Isolated from Calcareous Soil
}

\author{
Mahrous M. Kandil ${ }^{* 1}$
}

\begin{abstract}
This study aimed to isolate and characterize bacterial strains capable of solubilizing tricalcium phosphate (TCP) as the most commonly and insoluble phosphate in soils. Normal and molecular approaches were used to isolate and characterize phosphate dissolving bacteria (PDB) adapted to arid and semi-arid climate conditions. In this study, two strains were successfully isolated and taxonomically classified as Pantoea sp. strain MK1D, and Erwinia sp. strain MK2Y based on sequences of their 16S rRNA gene and were given GenBank accession numbers KU358676 and KU358677, respectively. This was confirmed by the formation of large halo zones on both Pikovskaya (PVK) and National Botanical Research Institute's Phosphate (NBRIP) culture media. The significant bacterial growth on liquid media was associated with the reduction of $\mathrm{pH}$ from 7.0 to 2.0 which lead to $83 \%$ solubilization of added TCP of $0.75 \mathrm{~g} / \mathrm{L}$. This study confirmed that both PVK and NBRIP media were reliable and comparable for the isolation of PDB and measuring their efficiency. Further studies are needed to confirm the effectiveness of these strains under pot and field conditions and their potential for commercial biofertilizers production.
\end{abstract}

Keywords: Tricalcium phosphate, Pantoea sp., Erwinia sp., solubilization, PVK culture, NBRIP culture

\section{INTRODUCTION}

Phosphorus $(\mathrm{P})$ is second to nitrogen in amounts needed for optimal plant growth and yield. It is well known that most soils worldwide are rich in total inorganic and organic phosphorus, but are very poor in soluble and available P forms (McLaughlin et al. 2011). This is, in part, due to its precipitation, surface runoff, and adsorption onto soil minerals especially those rich in calcium and magnesium or iron and aluminum in alkaline and acidic soils, respectively (Richardson et al. 2009; McLaughlin et al. 2011). In general, available $P$ concentration in soil solution range from 0.001 to 0.2 $\mu \mathrm{g} / \mathrm{mL}$ representing only about $0.1 \%$ of total soil $\mathrm{P}$ (Brady and Weil 2002). Therefore, an annual application of chemical fertilizers is used to resupply soils with available P. However, about $90 \%$ of this annually added $\mathrm{P}$ is usually fixed in soils and becomes unavailable for plants and microbial growth (Sharma et al. 2013; Nash et al. 2014). This requires exploration of more efficient fertilizers and application methods, especially in developing countries where the production of low cost P fertilizers is limited. Long term strategies and solutions are needed from all countries to overcome the serious challenge of phosphate depletion and environmental pollution. The application of biofertilizers of effective phosphate solubilizing microorganisms is a promising biological solution to reeducate the depletion rate of RP reserve and potential environmental pollution during production of other fertilizers.

The use of phosphate dissolving bacteria (PDB) is documented to be an effective, environmentally safe, and economically valuable agricultural practice for improving soil P availability for plants (Subbarao 1988; Sharma et al. 2013). An important function of soil microorganisms is to supply nutrients for soil fertility, plant growth, and optimum crop production. Numerous efforts have been made to develop of specific media to isolate microorganisms capable of dissolving fixed or minimally- soluble forms of P (Pikovskaya 1948; Gupta et al. 1994; Nautiyal 1999). Many of these efforts successfully resulted in the isolation of several microbial species capable of dissolving sparingly soluble $\mathrm{P}$ forms such as Acinetobacter sp., Klebsiella sp., Enterobacter sp., Microbacterium sp., and Pseudomonas sp. (Islam et al. 2007). Ruangsanka (2014) recently reported the isolation of Buttiauxella izardii, Enterobacter cancerogenus, Burkholderia ubonensis, E. hormaechei, and Burkholderia pyrrocinia as PDB. Many other species were found effective as PDB belong to Pseudomonas, Mesorhizobium, Bacillus, Acetobacter, Burkholderia, Azotobacter, Klebsiella, Bacillus, Rhodococcus, Arthrobacter, Serratia, Chryseobacterium, Delftia, Gordonia, and Phyllobacterium (Pandey et al. 2006; Shin et al. 2015). Fungi such as Aspergillus, Penicillium, and Trichoderma spp. have also been found effective in phosphate solubilization (Illmer and Schinner 1995).

Calcareous soils are known to have a high content of calcium carbonate and low availability of $\mathrm{P}$ and micronutrients. Therefore, the isolation and

${ }^{1}$ Department of Soil and Water Science, Faculty of Agriculture, Alexandria University, Egypt

Running Title: Isolation of Phosphate Dissolving Bacteria

${ }^{*}$ Correspondence: Dr. Mahrous Kandil, Department of Soil and

Water Science, Alexandria University, Egypt

Email: mahrous.kandil@alexu.edu.eg Mobile: 651-331-6417

Received May 13, 2017, Accepted June 29, 2017 
characterization of new PDB recently became crucial toward finding effective and highly adapted PDB strains. This might lead to the production of effective commercial biofertilizers suitable for arid and semiarid climate conditions alternative to the expensive and environment damaging inorganic phosphorus fertilizers. The purpose of this study was to use traditional and molecular-based techniques to: 1) isolate and characterize phosphate-solubilizing bacteria from calcareous soils potential for expansion, 2) determine the ability of isolated strains to dissolve tricalcium phosphate as the most dominant inorganic source of phosphorus, and 3) determine possible mechanisms employed by the identified strains to dissolve TCP using two different culture media.

\section{MATERIALS AND METHODS}

\section{Culture media}

Two different culture media were used to isolate bacteria from soil with the ability to solubilize insoluble inorganic tricalcium phosphate (TCP). Pikovskaya's (PVK) medium (Pikovskaya 1948) contained $10.0 \mathrm{~g}$ glucose, $\quad \begin{array}{llllllll}5.0 & \mathrm{~g} & \mathrm{Ca}_{3}\left(\mathrm{PO}_{4}\right)_{2}, & 0.2 & \mathrm{~g} & \mathrm{KCl} & 0.1 & \mathrm{~g}\end{array}$ $\mathrm{MgSO}_{4} .7 \mathrm{H}_{2} \mathrm{O}, 0.5 \mathrm{~g}\left(\mathrm{NH}_{4}\right)_{2} \mathrm{SO}_{4}, 0.5 \mathrm{~g}$ yeast extract, $0.002 \mathrm{~g} \mathrm{MnSO}_{4} \cdot \mathrm{H}_{2} \mathrm{O}, 0.002 \mathrm{~g} \mathrm{FeSO}_{4} \cdot 7 \mathrm{H}_{2} \mathrm{O}$ and $16.0 \mathrm{~g}$ agar per liter of distilled water. The second medium is the National Botanical Research Institute's Phosphate growth medium (NBRIP) (Nautiyal 1999) which is devoid of yeast extract and contained $10.0 \mathrm{~g}$ glucose, 5.0 $\mathrm{g} \mathrm{Ca}_{3}\left(\mathrm{PO}_{4}\right)_{2}, 5.0 \mathrm{~m} \mathrm{~g} \mathrm{MgCl} 2.6 \mathrm{H}_{2} \mathrm{O}, 0.25 \mathrm{~g} \mathrm{MgSO}_{4} \cdot 7 \mathrm{H}_{2} \mathrm{O}$,

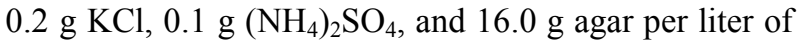
distilled water. The $\mathrm{pH}$ of both media was adjusted to 7.0 before autoclaving at $121{ }^{\circ} \mathrm{C}$ for $20 \mathrm{~min}$. Glucose was filter sterilized by using $0.22 \mu \mathrm{m}$ PFTE filter membranes and added to media after cooling to $45^{\circ} \mathrm{C}$. Both media were used as solid and as liquid to test the effectiveness of isolates qualitatively and quantitatively. The standard medium LB containing glucose $(10.0 \mathrm{~g})$, yeast extract $(5.0 \mathrm{~g}), \mathrm{NaCl}(5.0 \mathrm{~g})$, and agar $(18.0 \mathrm{~g})$ per liter of distilled water was also used. The LB is a rich medium to provide a faster growth and to support an easier morphological distinction among isolates. All chemicals used in this study were reagent grade or better.

\section{Collection and analysis of soil sample}

The soil used for bacterial isolation was collected from the surface layer $(0-20 \mathrm{~cm})$ using an acid washed stainless steel hand shovel at the Research Farm of Agriculture College, Fuka, Mersa Matrouh, at the North Western Coast of Egypt. For microbiological use, a fresh sample was transported in icebox to the laboratory and kept at $4{ }^{\circ} \mathrm{C}$ for $24 \mathrm{~h}$ before being used for bacterial isolation. A subsample soil was subjected to air drying, mixing, grinding in a porcelain mortar, and sieving (2 $\mathrm{mm})$. Samples were stored at room temperature in tightly closed plastic container before performing physical and chemical analyses. Composite soil sample was subjected to analysis following standard methods (Olsen et al. 1954; Page et al. 1982; Gee and Bauder 1986).

Isolation of phosphate-solubilizing bacteria by direct plating technique

Direct pour-plating method was used to isolate bacteria dissolving insoluble TCP from soil under investigation. Up to $10^{-5} \mathrm{Ten}$-fold serial dilutions of soil were made using $0.85 \%$ sterile $\mathrm{NaCl}$ solution and pourplated onto PVK medium initially. Plates were inversely incubated at $28{ }^{\circ} \mathrm{C}$ until large clearing zones were recognized in 3-7 days. Colonies forming halo zones were transferred and streaked onto solid PVK media for phosphate dissolving confirmation and for purification. Isolates were alternatively and successfully streaked onto solid LB and PVK media back and forth to distinguish colonies morphologically. This process was repeated 5-6 times to ensure purity of isolates and to confirm that they sustaining their ability to dissolve insoluble forms of phosphate. Morphological features, including colony size, shape, color, and transparency were used to distinguish potentially different isolates.

\section{Confirmation and solubility index calculation}

In addition to PVK, the NBRIP medium was used to confirm the capability of purified isolates to dissolve TCP. Single colonies of purified isolates were transferred by sterilized wood toothpicks and simultaneously stabbed into both solid PVK and NBRIP media. Plates were incubated at $28{ }^{\circ} \mathrm{C}$ and colonies monitored for the appearance of halo zones. Colony and halo zone diameters of each isolate, in both media, were measured daily and the solubility index was calculated by using the following equation (Edi Premono et al., 1996):

\section{$P S I=H a l Z \mathrm{~d} / C \ln \mathrm{d} \quad[\mathrm{Eq} .1]$}

where PSI is the solubility index, HalZd is the halo zone diameter (mm), and $C l n d$ is the colony diameter (mm).

Strains showing a high solubility index were selected for further study. Pure cultures were transferred to LB slants and kept in the refrigerator at $4{ }^{\circ} \mathrm{C}$ to be used for further studies. Pure cultures were also preserved in $20 \%$ sterile glycerol and stored at $-70{ }^{\circ} \mathrm{C}$ for long term storage. Unique strains were verified to dissolve inorganic precipitated phosphorus (TCP) in liquid NBRIP cultures as described below. 


\section{Quantitative measurements for phosphate solubilization and bacterial growth}

The efficiency of unique PDB strains isolated from calcareous soil in dissolving precipitated inorganic phosphorus was determined quantitatively by dissolving TCP in liquid broth. Strains were grown in NBRIP liquid medium, with three concentrations of TCP; 0.75, 2.0 , and $5.0 \mathrm{~g} / \mathrm{L}$. This experiment was conducted in $250-$ $\mathrm{mL}$ Erlenmeyer flasks containing $100 \mathrm{~mL}$ of sterilized NBRIP medium and incubated at $28{ }^{\circ} \mathrm{C}$ for $15 \mathrm{~d}$, on a rotary shaker at $150 \mathrm{rpm}$. Triplicate flasks were sampled nearly every other day under aseptic conditions for measurement of $\mathrm{pH}$, optical density at $600 \mathrm{~nm}\left(\mathrm{OD}_{600}\right)$, and released soluble $\mathrm{P}$. Culture $\mathrm{pH}$ was measured in the suspension without centrifugation or filtration. To measure $\mathrm{OD}_{600}$, decanted samples were left to stand for $1 \mathrm{~h}$ to allow any insoluble TCP precipitate to settle out of solution and the upper solution was used for measurement of $\mathrm{OD}_{600}$. To measure released $\mathrm{P}$, insoluble TCP and cell debris were pelleted by centrifugation at $6,000 \mathrm{xg}$ for $15 \mathrm{~min}$ and the supernatant was used for the determination of soluble $\mathrm{P}$ in solution using the colorimetric blue ammonium molybdate method with measurement at $882 \mathrm{~nm}$ (Murphy and Riley 1962). The quantities of released $\mathrm{P}$ in supernatant were determined using a $\mathrm{KH}_{2} \mathrm{PO}_{4}$ standard curve with concentrations ranging from 0 to $6 \mathrm{mg} \mathrm{P} / \mathrm{L}$. Samples higher than that range were diluted to fit the range. Dilution factor was used to calculate the concentration of $\mathrm{P}$.

\section{Molecular identification of unique PDB isolates}

The 16S rRNA gene of morphologically distinct isolates was amplified, purified, and sequenced to identify unique PDB bacterial isolates. A single colony of each isolate was selected, picked with a $1-\mu 1$ sterile inoculating loop (Fisher Scientific, Pittsburgh, PA), and suspended in $100 \mu \mathrm{l}$ of sterile solution of $0.05 \mathrm{M} \mathrm{NaOH}$ in $1 \mathrm{ml}$ Eppendorf tube. Tubes were boiled (99 to 100 ${ }^{\circ} \mathrm{C}$ ) for 15 minutes for cell lysis. Tubes were centrifuged for $10 \mathrm{~min}$ at $6,000 \mathrm{rpm}$ to separate DNA-containing supernatant from cell debris. A $2 \mu$ aliquot of the supernatants were used as DNA templates for PCR reactions for $16 \mathrm{~S}$ rRNA gene amplification (Weisburg et al.1991). The forward primer 27f (5'AGAGTTTGATCMTGGCTCAG-3') and reverse primer 1492r (5'-CTACGGCTACCTTGTTACGA-3') (Integrated DNA Technologies, Coralville, Iowa) were used. PCR mixture $(50 \mu \mathrm{l})$ contained sterilized Millipore nuclease free water $(38.5 \mu \mathrm{l}), 10 \mathrm{X}$ PCR buffer $(5 \mu \mathrm{l})$, dNTPs $(2 \mu \mathrm{l}), 27 \mathrm{f}$ primer $(1 \mu \mathrm{l}), 1492 \mathrm{r}$ primer $(1 \mu \mathrm{l})$, DNA template $(2 \mu \mathrm{l})$, and Choice Taq Polymerase $(0.5$ $\mu \mathrm{l})$. PCR was performed using an MJ research PTC 100 (MJ Research, Waltham, Mass., USA) thermocycler. The PCR program was as follow: initial denaturing step for $95{ }^{\circ} \mathrm{C}$ for $10 \mathrm{~min}$, followed by 34 cycles of $95{ }^{\circ} \mathrm{C}$ for $30 \mathrm{sec}, 57{ }^{\circ} \mathrm{C}$ for $45 \mathrm{sec}$, and $72{ }^{\circ} \mathrm{C}$ for $1.5 \mathrm{~min}$ with a final extension step for $6 \mathrm{~min}$ at $72{ }^{\circ} \mathrm{C}$ in an automated thermal cycler then a storing step at $4{ }^{\circ} \mathrm{C}$. The PCR products were examined for successful amplification by using gel electrophoresis as described elsewhere (Kandil et al. 2015).

\section{Purification and sequencing of $16 S$ rRNA gene}

The confirmed 16S rRNA PCR products were purified by using QIAquick PCR purification Kit (Qiagen, Valencia, CA, USA), and the concentration of the purified DNA was determined by Qubit 2.0 fluorometer (Invitrogen, Life technologies, Carlsbad, CA). Samples were submitted to ACGT, Inc (Wheeling, IL) for Sanger sequencing of both DNA strands, using the $27 \mathrm{f}$ and $1492 \mathrm{r}$ primers. Consensus sequence contigs of both strands was generated using BioEdit software (Hall 1999) and compared with GenBank database of nucleotides by using the BLASTn algorithm (Altschul et al. 1990). A Phylogenetic tree was generated for interrelationships among the strains using MEGA7software (Kumar et al. 2016).

\section{RERSULTS AND DISCUSSION}

\section{Successful Isolation of PDB from Calcareous Soil}

Based on soil analysis, sample was classified as sandy clay loam (61\% sand, $24 \%$ silt and $15 \%$ clay) with a pH 8.28 (2:1, water:soil), electrical conductivity (EC) $2.32 \mathrm{mS} / \mathrm{Cm}$ (2:1, water:soil), organic matter $0.17 \%, 5.7 \mathrm{ppm}$ available $\mathrm{P}$, and $26.7 \%$ total carbonate. Soil of this region is classified as Calcaric Fluvisols and Calcic Yermosols (El-Nahrawy, 2011). Using direct plating methods described above, several halo zones were recognized on PVK plates. Initially, these halo zones contained several mixed bacterial cultures and were transferred to fresh PVK plates for purifications. At the same time, several colonies appeared on PVK but without forming clearing zones and thus were eliminated. For purification, colonies clearing TCP were transferred and streaked back and forth onto fresh PVK and LB plates alternately several times for fast growth and distinct morphological features. Figure 1A shows some halo zones surrounding colonies as they grow on PVK medium (left plate, Fig. 1A). These colonies were streaked later onto NBRIP solid medium and showed a full clearing of TCP precipitate (right plate, Fig.1B).

\section{Selection of highly effective isolates based on solubility index}

Based on the diameters of both halo zone and colony, phosphate solubility index $(P S I)$ was calculated as described above by Eq.1. Data showed that solubility index varied among isolates, incubation time, and 
media. As shown in Fig. 2, although isolates showed higher PSI values on PVK medium that that on NBRIP, both media were reliable and effective for the selection and comparison of highly effective PDB strains. Also, data showed that solubility index for each strain was not a fixed value but have changed over time during incubation. Data showed that an incubation period of 45 days is reasonable for the selection of potential PDB strains and there was no need to wait for more days to identify effective isolates.

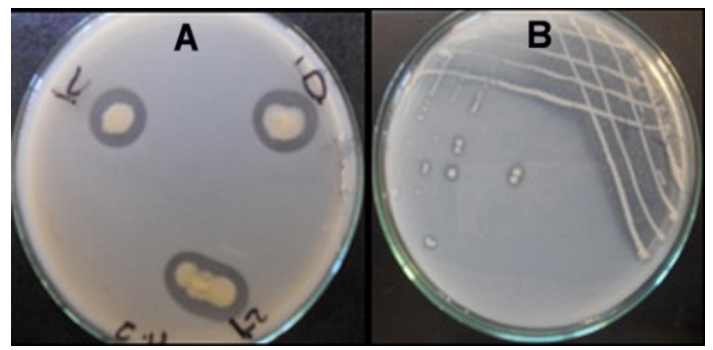

Fig. 1 (A). Halo zones formed by the growth of the isolates on PVK medium supplemented with TCP $(5.0 \mathrm{~g} / \mathrm{L})$ and $(B)$ solubilization of TCP $(5.0 \mathrm{~g} / \mathrm{L})$ shown as cleared streaked area of NBRIP plate by one of the isolates

Quantitative Measurements for Phosphate Solubilization and Bacterial Growth

Since the solubility index is a qualitative indicator as it varies, based on incubation time, strain, and media, liquid media must be used to quantitatively examine the effectiveness of isolates to solubilize phosphate and determine mechanism(s) by which this is occurring. Results in Figs. 3, 4, and 5 show the growth curves $\left(\mathrm{OD}_{600}\right)$ of these isolates, their effect on $\mathrm{pH}$ of inoculated culture media, and concentration of released soluble P, respectively. Results in Fig. 3 showes that while growth curves had a standard sigmoidal shape, isolates differed in their maximum growth. As shown in Fig.4, growth of isolates was concomitant with a significant reduction of the culture $\mathrm{pH}$ from 7 to 2 . $\mathrm{Ph}$ is the most important factor controlling the solubility and availability of $\mathrm{P}$ in cultures and soils. Concurrent with the reduction in $\mathrm{pH}$, there was a significant increase in solublizied $\mathrm{P}$ up to $83 \%$ comapred to the uninoculated control treatment (Fig. 5). Among isolates tested, strain MK1D showed the greatest growth concurrent with the lowest $\mathrm{pH}$ and the greatest amount of solubilized P. Several other isolates were eliminated for further studies due its limited amount of released P.
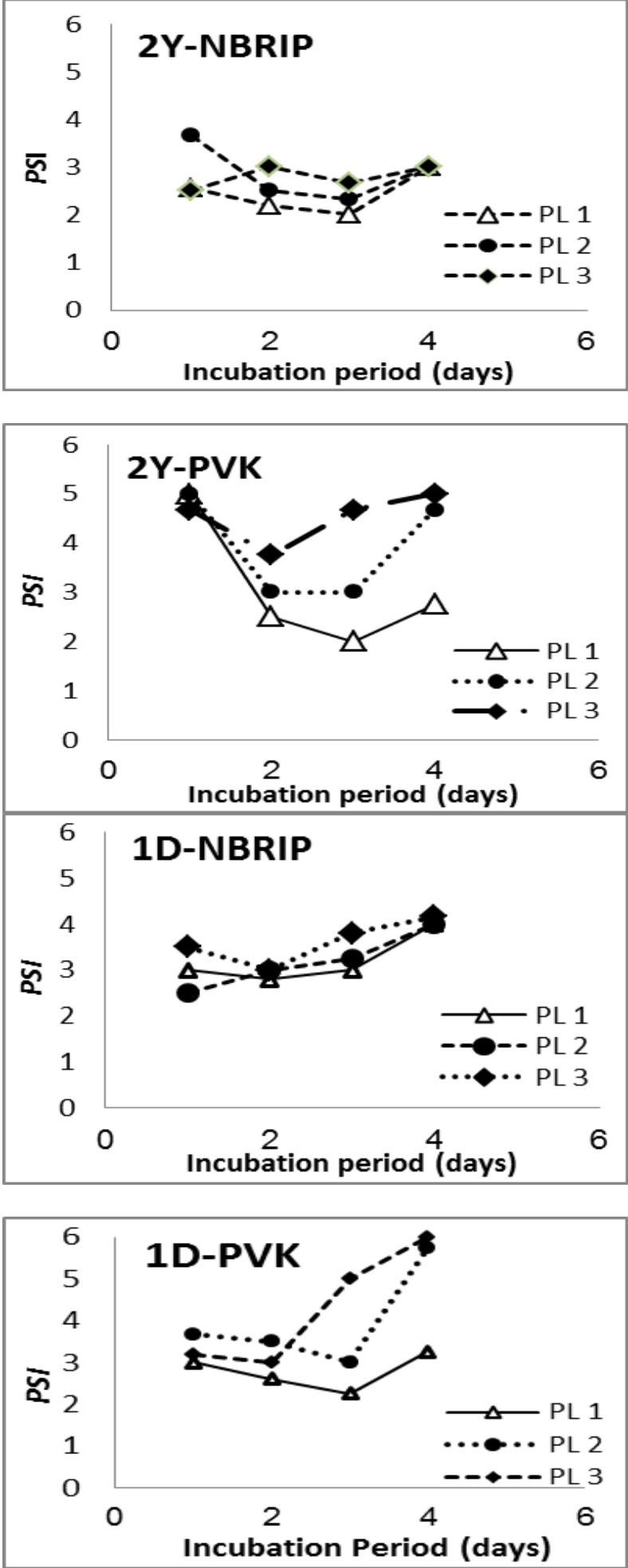

Fig. 2. Phosphate solubility index (PSI) for isolates MKID and MK2Y cultured on both PVK and NBRIP as labeled. Diameters of halo zones and colonies were used for PSI calculation as in Eq.1. Each plate (PL) was treated as a treatment replicate 


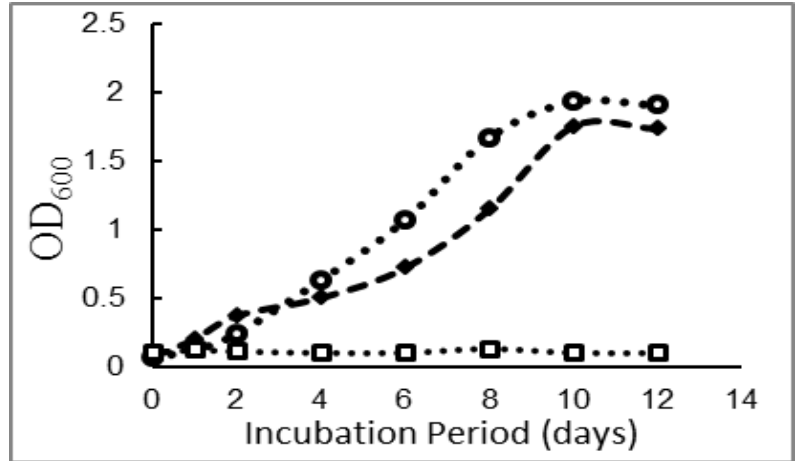

Fig. 3. The growth of strains Pantoea sp. strain MKID (४) and Erwinia sp. strain MK2Y (O) on NBRIP liquid medium supplemented with $750 \mu \mathrm{g} / \mathrm{mL}$ TCP against Control ( $\square$ )

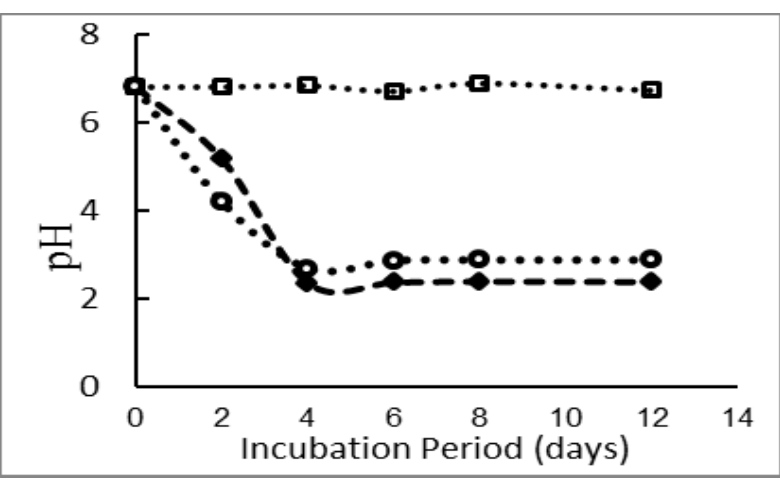

Fig. 4. Changes of culture $\mathrm{pH}$ due to the of growth of strains Pantoea sp. strain MKID ( () and Erwinia sp. strain MK2Y (O) on NBRIP liquid medium supplemented with $750 \mu \mathrm{g} / \mathrm{mL}$ TCP; Control ( $\square$ )

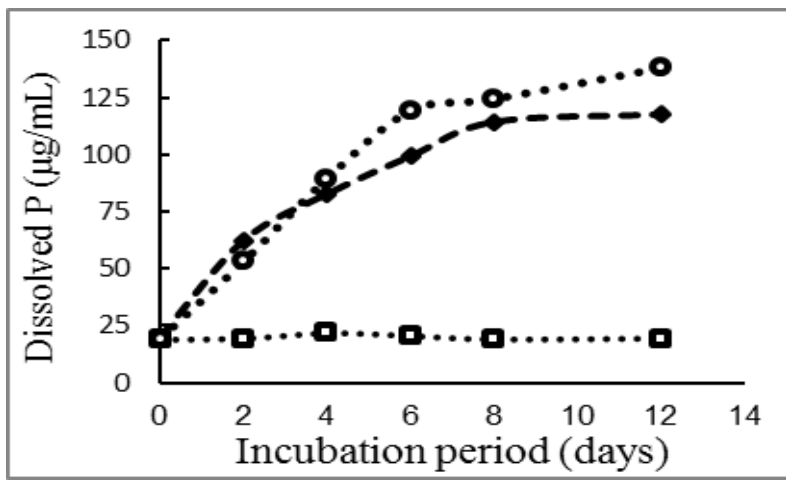

Fig. 5. Solubilization of TCP and amounts of released $P$ during the growth of strains Pantoea sp. strain MKID ( $\diamond)$ and Erwinia sp. strain MK2Y (O) on NBRIP liquid medium supplemented with 750 $\mu \mathrm{g} / \mathrm{mL}$ TCP compared to control ( $\square$ )

\section{Taxonomic Identification of isolated PDB Strains}

After confirming the effectiveness of these isolates in dissolving TCP, the taxonomic identity of the most efficient TCP-solubilizing isolates was determined by the analysis of almost full length sequence of their $16 \mathrm{~S}$
rRNA gene. Based on BLASTn searches, the sequences of the $16 \mathrm{~S}$ rRNA genes of the isolates ranged from $97 \%$ to $99 \%$ identical to several strains in genomic database. Using 16S rRNA sequences of the isolated strains and their closely related species, phylogenetic tree was constructed (Figs. 6 \& 7) based on Unweighted Pair Group Method with Arithmetic Mean (UPGMA) method and rooted to an $E$ coli strain. The $16 \mathrm{~S}$ rRNA gene from isolate MK1D was $99 \%$ identical to Pantoea sp. B21 (JX010971.1), Pantoea sp. B28 (KF479585.1), Pantoea agglomerans Ast1 (GU204957.1), and Pantoea agglomerans strain BJ-Tobacco. As shown in Fig. 7, isolate MK2Y was found to be $99 \%$ identical to Erwinia persicina WD1608 (EU681952.1), Erwinia sp. UIWRF0140 (KR189887.1), and Erwinia persicina S9 (KP715898.1). This is one of the few studies reporting that some strains of Erwinia spp. are characterized as phosphate dissolving bacteria (Rodríguez et al. 2000; Ivanova et al. 2006). Evolutionary relationships of taxa for Pantoea sp. strain MKID (Fig. 6) and for Erwinia sp. strain MK2Y (Fig. 7) were inferred using the UPGMA method (Sneath and Sokal 1973). The percentage of replicate trees in which the associated taxa clustered together in the bootstrap test (100 replicates) is shown next to the branches (Felsenstein 1985). All positions containing gaps and missing data were eliminated. The evolutionary distances were computed using the Jukes-Cantor method (Jukes and Cantor 1969). Evolutionary analyses were conducted in MEGA7 (Kumar et al. 2016). Both trees were rooted to $E$ coli (KP789329.1).

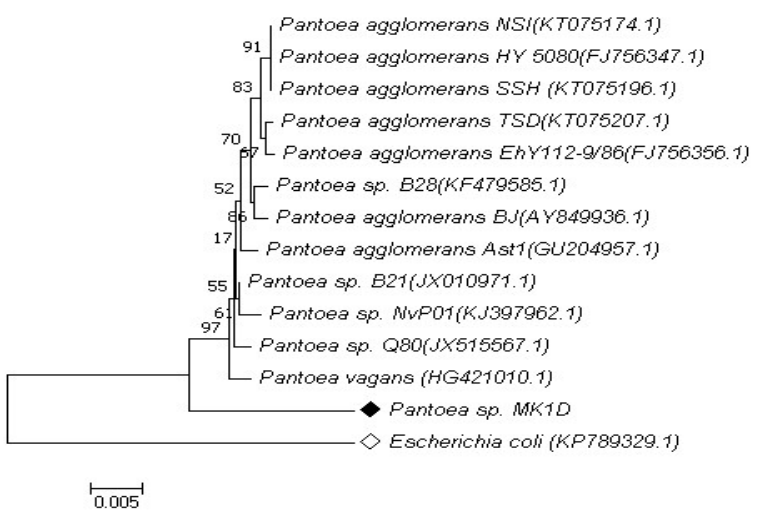

Fig. 6. Evolutionary relationships of taxa for Pantoea sp. strain MKID. The evolutionary history was inferred using the UPGMA method. The optimal tree with the sum of branch length $=\mathbf{0 . 0 8 4 7 0 4 2 3}$ is shown. The tree is drawn to scale, with branch lengths in the same units as those of the evolutionary distances used to infer the phylogenetic tree. The analysis involved 14 nucleotide sequences. There were a total of 1428 positions in the final dataset 


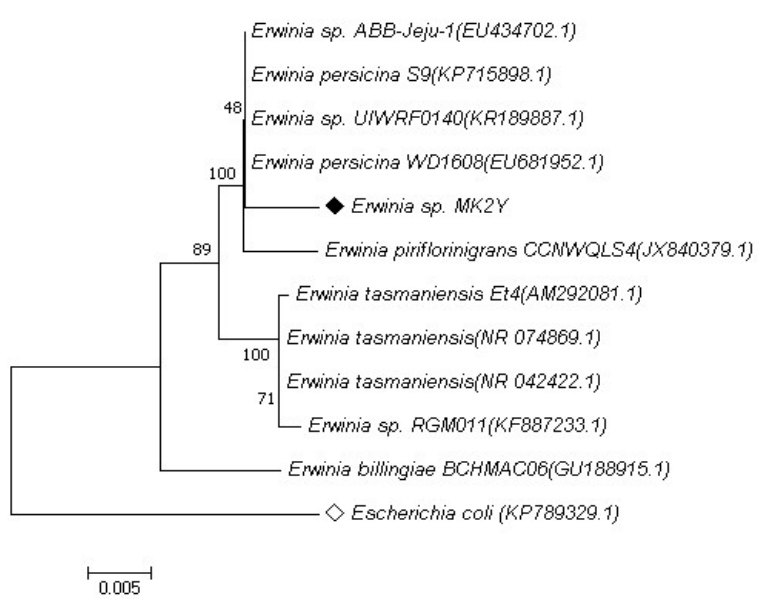

Fig. 7. Evolutionary relationships of taxa for Erwinia sp. strain MK2Y. The evolutionary history was inferred using the UPGMA method. The optimal tree with the sum of branch length $=\mathbf{0 . 0 7 0 6 2 1 6 3}$ is shown. The tree is drawn to scale, with branch lengths in the same units as those of the evolutionary distances used to infer the phylogenetic tree. The analysis involved 12 nucleotide sequences. There were a total of 1207 positions in the final dataset

\section{CONCLUSIONS}

In this study, two bacterial strains were isolated from calcareous soil located at Fuka Agricultural Research Farm, Mersa Matruh and were confirmed to be highly effective in solubilizing TCP, the most dominant and insoluble inorganic forms of phosphorus in calcareous soils. Based on nearly full length analysis of 16S rRNA genes, these strains were taxonomically identified as Pantoea sp. strain MK1D and Erwinia sp. strain MK2Y. This is especially important for soils with poor conditions such as calcareous soils under arid and semiarid climate conditions where these strains are well adapted. However, for the production of highly effective phosphate biofertilizers, further pot and field studies are needed.

\section{ACKNOWLEDGEMENT}

Author is grateful to Prof. Michael Sadowsky, University of Minnesota, USA for bench space and financial support for DNA sequencing. Also author is thankful to Prof. Mohamed El-Halfawi, Alexandria University, Egypt for his valuable comments during lab work. Author thanks Ms. Gehad Elsherbini for her technical assistance. This research was supported by the University of Minnesota and Alexandria University.

\section{REFERENCES}

Altschul S.F., W. Gish, W. Miller, E.W. Myers, and D.J. Lipman. 1990. Basic local alignment search tool. J Mol Biol 215(3):403-410.
Brady N. C., and R.R. Weil. 2002. The Nature and Properties of Soils, $13^{\text {th }}$ edn. Prentice Hall of India, New Delhi, pp. 960.

Edi Premono M., A.M. Moawad, and P.L.G. Vlek. 1996. Effect of phosphate-solubilizing Pseudomonas putida on the growth of maize and its survival in the rhizosphere. Indones. J. Crop Sci. 11, 13-23.

El-Nahrawy M.A. 2011. Country pasture/forage resource profiles: $\quad$ Egypt. http://fao.org/ag/agp/agpc/doc/counprof/egypt/egypt.html, Accessed on June 15, 2017.

Felsenstein J. (1985). Confidence limits on phylogenies: An approach using the bootstrap. Evolution 39:783-791.

Gee G.W., and J.W. Bauder.1986. Particle-size analysis. In: Klute A (ed) Methods of Soil Analysis, Part 1: Physical and mineralogical methods. Agronomy Monograph No. 9 ( $2^{\text {nd }}$ edn), ASA/SSSA, Madison, WI, pp: 383-411.

Gupta R., R. Singal, A. Shankar, R. Chander, and S.R. Kumar. 1994. A modified plate assay for screening phosphate solubilizing microorganisms. J Gen Appl Microbiol 40:255-260

Hall T.A.1999. BioEdit: a user-friendly biological sequence alignment editor and analysis program for Windows 95/98/NT, in: Nucleic acids symposium series 41:95-98.

Illmer P. and F. Schinner. 1995. Solubilization of inorganic calcium phosphates-solubilization mechanisms. Soil Biol Biochem 27: 257-263

Islam M.T., A. Deora, Y. Hashidoko, A. Rahman, T. Ito, and S. Tahara. 2007. Isolation and identification of potential phosphate solubilizing bacteria from the rhizoplane of Oryza sativa L. cv. BR29 of Bangladesh. Zeitschrift fur Naturforsch. - Sect C J Biosci 62(1-2):103-110.

Ivanova R, D. Bojinova, and K. Nedialkova. 2006. Rock phosphate solubilization by soil bacteria. Chem Technol 297-302.

Jukes T.H. and C.R. Cantor.1969. Evolution of Protein Molecules. In Munro H.N, editor, Mammalian Protein Metabolism, pp. 21-132, Academic Press, New York.

Kandil M.M., C. Trigo, W.C. Koskinen, M.J. Sadowsky. 2015. Isolation and characterization of a novel Imidacloprid-degrading Mycobacterium sp. strain MK6 from an Egyptian soil. J Agric Food Chem 63:4721-4727.

Kumar S., G. Stecher, and K. Tamura. 2016... MEGA7: Molecular Evolutionary Genetics Analysis version 7.0 for bigger datasets. Molecular Biology and Evolution 33:1870-1874.

McLaughlin M.J., T.M. McBeath, R. Smernik, S.P. Stacey, B. Ajiboye, and C Guppy. 2011. The chemical nature of $\mathrm{P}$ accumulation in agricultural soils-implications for fertiliser management and design: An Australian perspective. Plant Soil 349:69-87.

Murphy J., and I.P. Riley. 1962. A modified single solution method for the determination of phosphate in natural waters. Anal Chim Acta 27:31-36. 
Nash D.M., P.M. Haygarth, B.L. Turner, L.M. Condron, R.W. McDowell, A.E. Richardson, M. Watkins, and M.W. Heaven. 2014. Using organic phosphorus to sustain pasture productivity: A perspective. Geoderma 221222:11-19 doi:10.1016/j.geoderma.2013.12.004.

Nautiyal C.S. 1999. An efficient microbiological growth medium for screening phosphate solubilizing microorganisms. FEMS Microbiol Lett 170:265-270.

Olsen S.R., C.V. Cole, F.C. Watanabe, and L.A. Dean. 1954. Estimation of available phosphorus in soils by extraction with sodium bicarbonate. USDA Cir.939 USDA, Washington, DC.

Page A.L., R.H. Miller, and D.R. Keeney (1982) Methods of Soil Analysis, Part 2: Chemical and microbiological properties. Agronomy Monograph No. 9 ( $2^{\text {nd }}$ Edn), ASA, Madison, WI.

Pandey A., P. Trivedi, B. Kumar, and L.M.S. Palni. 2006. Characterization of a phosphate solubilizing and antagonistic strain of Pseudomonas putida (B0) isolated from a sub-alpine location in the Indian Central Himalaya. Curr Microbiol 53:102-107.

Pikovskaya R.I.1948. Mobilization of phosphorus in soil in connection with the vital activity of some microbial species. Mikrobiologiya 17:362-370.
Richardson A.E., J.M. Barea, A.M. McNeill, and C. PrigentCombaret. 2009. Acquisition of phosphorus and nitrogen in the rhizosphere and plant growth promotion by microorganisms. Plant Soil 321:305-339.

Rodríguez H., Gonzalez T., and G. Selman. 2000. Expression of a mineral phosphate solubilizing gene from Erwinia herbicola in two rhizobacterial strains. J Biotechnol 84:155-161.

Ruangsanka S. 2014. Identification of phosphate-solubilizing bacteria from the bamboo rhizosphere. ScienceAsia 40:204-211.

Sharma S.B., R.Z. Sayyed, M.H. Trivedi, T.A. Gobi. 2013. Phosphate solubilizing microbes: sustainable approach for managing phosphorus deficiency in agricultural soils. Springerplus 2:587.

Shin D., J. Kim, B. Kim, J. Jeong, and J. Lee. 2015 Use of phosphate solubilizing bacteria to leach rare earth elements from monazite-bearing ore. Minerals 5:189-202.

Sneath P.H.A. and R.R. Sokal. 1973. Numerical Taxonomy. Freeman, San Francisco.

Subbarao N.S. 1988. Phosphate Solubilizing Microorganism. In: Biofertilizer in Agriculture and Forestry. Regional Biofert. Dev Centre, Hissar, India. pp. 133-142.

Weisburg W.G., S.M. Barns, D.A. Pelletier, and D.J. Lane. 1991.16S ribosomal DNA amplification for phylogenetic study. J Bacteriol 173:697-703. 


\section{الملخص العربي \\ Pantoea Sp. Strain MK1D \\ توصيف سلالتي \\ التربة الجيرية كبكتيريا مذيبة لفوسفات ثثلاثي الكالسيوم \\ محروس قنديل}

السلالتين عل إذابة فوسفات ثلاثي الكالسيوم المترسب في

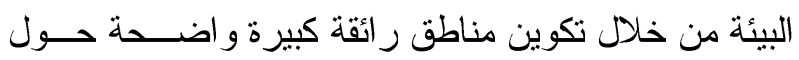

مستعمر اتها عند نمو ها على كل من بيئة بيكوفسكايا (PVK)

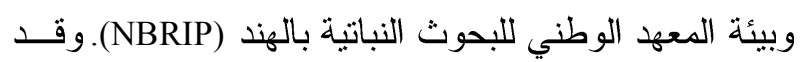

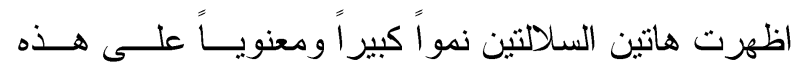

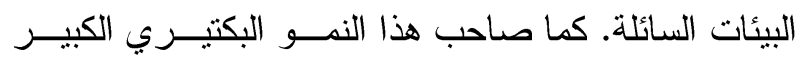

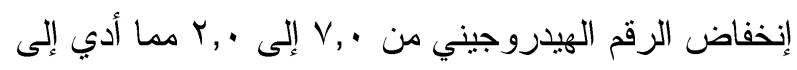

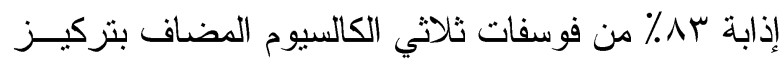

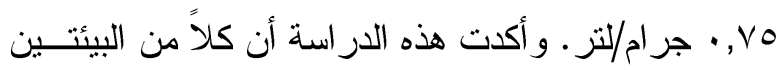

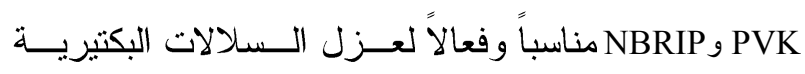

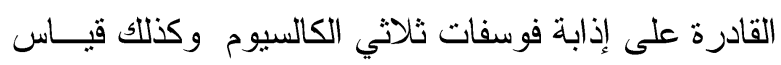
كفاءتها. و وبالرغم من نجاح هذه الدر اسة كخطوة أولى، فإن لـان

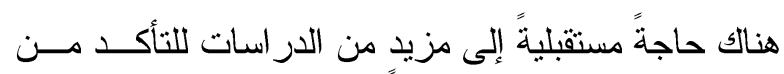

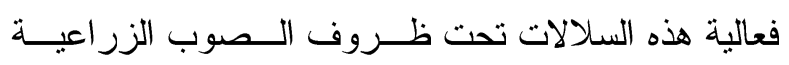
و الحقلية وإمكانية إنتاجهاضمن الأسمدة الحيوية التجارية.
تهدف هذه الدر اسة إلى عـزل وتوصـيف الـسلالات

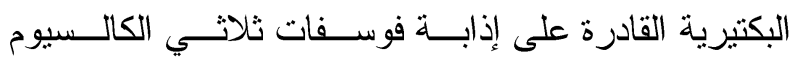

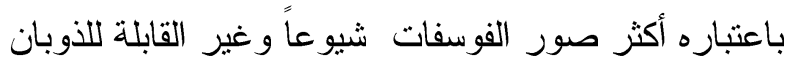
في التربة. كما تهدف الدراسة أيضاً مقارنة كفــاءة البيئسـة

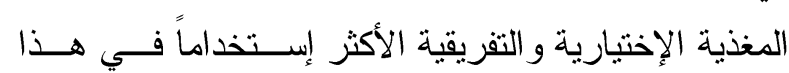

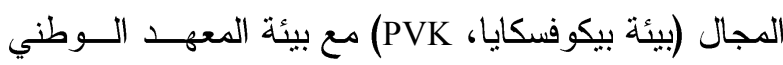

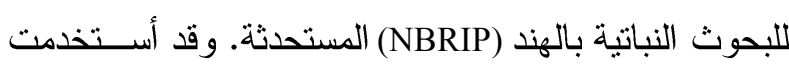

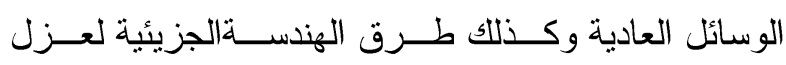

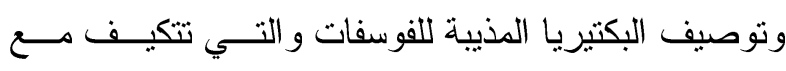
الظروف المناخية للمناطق الجافة وشبه الجافة. هذا وقد تم

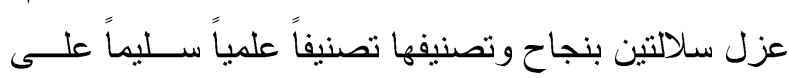
أساس التسلسل النيوكلوتيدي لجين rRNA Pantoea sp. strain MK1D, and Erwinia لكلاهما وسميتا كماتم تسجيل هاتين السلالثنين في بنــــ sp. strain MK2Y

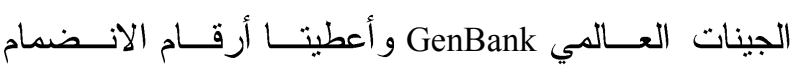

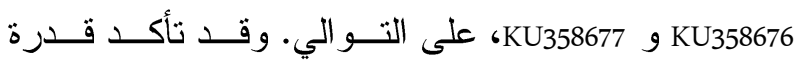

